\title{
THE EMPRESS WITH TWO HEADS
}

\section{BOŽIDAR JEZERNIK}

In my paper I discuss the story associated with the head of the statue of Empress Livia from a temple dedicated to the emperor's cult in Roman Narona (the present-day Vid). The head is kept in the Ashmolean Museum in Oxford. While in the main gallery of the museum its plaster cast is exhibited with a note explaining that the original head is currently on permanent loan in the Archaeological Museum of Split, but in the gallery with Roman antiquities the original head of the statue is displayed with a note explaining that it was obtained by a famous archaeologist Arthur John Evans during his travels to Dalmatia.

Not just the head of Livia's statue, but also her body has been preserved. It is 'temporarily' kept in a huge wooden box in the public library of Opuzen while the main piazza is being reconstructed to realise Opuzen's hundred-year long dream which will culminate in the opening of a new museum dedicated to Livia.

Keywords: The Augusteum, Croatian Archaeology, Livia, Salona and Narona.
$V$ prispevku obravnavam zgodbo, povezano z glavo kipa cesarice Livije iz templja, posvečenega cesarskemu kultu, $v$ antični Naroni (današnji Vid). Glava je danes v hrambi Ashmolejevega muzeja v Oxfordu. V glavni dvorani stoji njen mavčni odlitek s pripisom, da je izvirna glava $v$ Arheološkem muzeju Split na posodo za nedoločen čas, medtem ko je v prostoru z rimskimi starinami stoji posebej razstavljena izvirna glava Livijinega kipa, s pripisom, da jo je pridobil znameniti arheolog Arthur John Evans med svojimi potovanji po Dalmaciji.

Poleg glave Livijinega kipa je obranjeno tudi njeno telo, za katero v mestu Opuzen pripravljajo poseben muzej, ki naj bi predstavljal uresnicitev stoletnih sanj njegovih prebivalcev. Stoletne sanje se, razumljivo, uresničujejo počasi, tako tudi v tem primeru. Tako je telo Livijinega kipa zdaj "začasno"shranjeno v velikem lesenem zaboju, postavljenem $v$ prostorih mestne knjižnice.

Ključne besede: avgusteum, hrvaška arheologija, Livija, Salona in Narona.

Emperor Francis I-as well as the last Holy Roman Emperor Francis II-took great interest in Dalmatia, and visited the Roman ruins of Salona in 1818. Three years later, he initiated first archaeological excavations in Dalmatia, which started in Salona and Pola. The operations were carried on with some interruptions until 1877 due to the lack of funds (Paton 1862: I, 314-315; Jelić, Bulić in Rutar 1894: 43; Munro 1895: 238; Bulić 1924/25: 18). In all probability, this 'want of funds' was not entirely fortuitous. At the turn of the century, dreams of bringing the Holy Roman Empire back to life had been buried; and the Austrian people were more interested in Greece than in Dalmatia (Bahr 1909: 35). Accordingly, the first archaeological digs in Narona were recorded in 1877, while major archaeological research was only conducted in the early twentieth century by Karl Patsch, the author of the first monograph on Narona (Patsch 1907). 


\section{A CARRIAGE AND A PAIR OF BLACK HORSES}

For decades, the ancient site of Salona stood out as the parade horse of Croatian archaeology, and was advertised as "the cradle of Croatian culture". This would change when Dr Emilio Marin, at the end of the twentieth century, started with archaeological excavations on the site of ancient Narona. The then Croatian minister of culture commented: 'I am afraid that Narona will overtake Salona.' Marin replied: "There is a carriage and a pair, in which one black horse is Salona and the other Narona" (Marin 1999: 287).

The Roman town of Narona had already been renowned five centuries before our era, and it had thrived till its destruction in the seventh century; subsequently a pirate town sprang up on its ruines. The present name of the village Vid derives from the name of the Slavic pagan god Vid, to whom a temple had been reared here by the conquerors of Narona: In the year 639 A. D. Narona, which till then had remained a flourishing Roman city, was reduced to ashes by a mingled horde of Avars and Sclaves, and a few years later the Serbian Sclaves called in by the Emperor Heraclius took possession of the vacant sites of the lower Narenta. Out of the ruins of the Roman Narona they built a new town, and here, on the sites of classic temples, reared a fane to a Sclavonic god, whose name, Viddo, is still perpetuated in that of the modern village. The site of this Illyrian Narbonne thus became a stronghold of heathendom in these parts, just as with the Sclavonians of the Baltic shores Paganism found its last defenders among those staunch Rügen islanders who guarded the precincts of the sacred city of Arona. It was not till the year 873 that Nicetas, the Admiral of the Byzantine Emperor Basil, previled on the Narentines to accept baptism; the temple of their country's god underwent a strange conversion, and Viddo lived again in a Christian guise as St. Vitus! (Evans 1876: 363)

\section{A MYSTERY OF HEADLESS TORSOS}

The archaeological excavations on the site of the ancient Narona continued only after the Second World War, and, in the mid-1990s, the director of the Archaeological Museum in Split Emilio Marin succeeded in digging up the most remarkable relics of the Roman past, a temple dedicated to the cult of the imperial family of Augustus. It contained two marble statues of Augustus, a Tiberius, a Vespasian and a Claudius, as well as various empresses and unidentified figures (Marin 1999). The Augusteum in Narona was built in the last decade BC, when the first statues were erected, including one colossal and one life-size statue of Emperor Augustus. For more than three centuries some twenty images of the imperial family had been idiolised, but in the $4^{\text {th }}$ century $\mathrm{AD}$ the temple was destroyed. When unearthed, all its statues were headless torsos, lying prone on the mosaic floor. It 
seems that they were knocked down somewhere around the year 390. According to Dr Marin there were two potential causes for this:

One might be state or political when, towards the end of the 4 th century, Theodosius issued an edict that any remaining pagan sanctuary should be destroyed. The destruction may have been the direct consequence of this imperial decree. The other reason might be of more local character. If at that time (and this cannot be ascertained) there were a strong Christian community in Narona, this community may have been irritated by the existence of that old pagan cult and might have destroyed the temple. (Marin 1999: 312; see also Prusac 2011: 515)

Marin's hypothesis was that there were two statues dedicated to Augustus in the temple, one erected during his life time, and the other after his death when he was deified. For Marin it was also reasonable to suppose that the Augusteum contained a statue of Augustus's wife, the Empress Livia, her cult at Narona being attested by a cameo with Livia's portrait and inscriptions unearthed in Vid, as well as by the portrait head in the Ashmolean Museum in Oxford, acquired by Arthur (later Sir) Evans in 1878 (Marin 2004: 76).

As a result, when a headless, female torso was unearthed, he anticipated that it was Livia's. Marin's anticipation was announced in The Times, on 25 October 2000, together with his plaint for the Ashmolean Museum to return the head back to Croatia although he admitted that he did not expect them to comply: "We would like to have the head back, of course, but I don't expect the Ashmolean Museum to offer it to us," he said (Hammond 2000a: 24; 2004: 32) However, it happened that the Ashmolean's governing body was meeting the next day, and promptly volunteered to send Livia's head on a one-year loan to the Archaeological Museum in Split (J. Z. N. 2000: 3; Vickers 2001: 9; Hammond 2004: 32).

\section{ALL TOGETHER NOW}

When, on 16 December 2000, Curator Michael Vickers brought Livia's head from Oxford to Split, the attempt to match the head with the body of the statue, supposedly belonging to Livia, was unsuccessful as the neck was too thin to fit the socket on the body. Marin concluded that his hypothesis that the life-size Oxford Livia's head and colossal statue no. 4 might have belonged together "was not supported by the technical evidence, although they were compatible in marble type, chronology and style" (Marin 2004: 76). He continued his search for a torso to match the head from Oxford. This lasted for some time and attracted great media attention, not only, if mainly, in Croatia, but also in Britain. There were six articles dedicated to the Livia of Narona published by Norman Hammond, professor emeritus of archaeology at Boston University, and The Times correspondent for archaeology, in the following five years, openly favouring the idea of returning the marble head to Croatia (Hammond 2000a, b, 2001a, b, 2004, 2005). 
Eventually, Marin found a suitable life-size body for the head. He did not have to dig it up as it was already standing in the town hall of a nearby town of Opuzen. The torso was first mentioned by Sir Gardner Wilkinson who wrote about it in his travelogue published in 1848. During his travels in Dalmatia, Sir Gardner Wilkinson paid a short visit to the village of Vid where he observed fragments of Roman sculpture and inscriptions (Wilkinson 1848, II: 23-24). ${ }^{1}$ He also visited the nearby town Fort Opus where Pretore Anđelo Vidović showed him "some ancient fragments, brought from Vido, the ancient Narona," which he used as decoration for the terrace of his house. Amongst the fragments were also "the torso of a Roman Emperor in armour' and the headless 'statue of a female, drapped, probably a vestal" (Gardner Wilkinson 1848, II: 13-15).

Marin was acquainted with Sir Gardner Wilkinson's travelogue. So, he, together with his British colleagues visited Opuzen, on 22 January 2001, and examined a life-size female torso which had been dated stylistically to the $2^{\text {nd }}$ century, a hundred years too late to match Livia's head. As the neck socket looked the right size, they nevertheless tried and put the cast of the Oxford head on it. This time it was s undoubtedly attested that they made "a perfect join". As part of the drapery on the torso matched a small trace on the side of the head, where the mantle was drawn closely in on both sides, all agreed that the join was "a real one" (Hammond 2001b: 24, 2004: 32; Marin 2004: 76).

As Vickers recollected, the Croatian press and TV were there in force. There were speeches in French, Italian, English and Croatian. In Vickers' speech he said that he had come as a pilgrim, not like most pilgrims of the time who shoot past Vid in their millions on their way to the shrine of Medjugorje, but as a pilgrim in the footsteps of Arthur Evans.

I told the story of acquisition of the Livia head as related to me by Dame Joan Evans when she gave the Ashmolean another marble head (of Hermes) from Narona in 1974: how their father Sir John Evans told his son that he would meet lots of important people in the Balkans and that he should be appropriately dressed. A top hat could be de rigeur. Duly equipped with a top hat from Lock's in St James's, Arthur set off on his travels, but never had the opportunity to don his headgear. Offered the heads of Livia and Hermes, he gave the owner the top hat, and put the heads in the leather hatbox. (He ran up so many debts in the Balkans that his father offered to clear them by buying the marble heads from him; Arthur eventually regained the Livia, which he bequeathed to the Ashmolean in 1941, and Joan was bequeathed the Hermes.) (Vickers 2001: 9-10)

At any rate, in 2001, the head and body of Livia were reunited. Dr Christopher Brown, director of the Ashmolean Museum, congratulated "our colleagues in Split on their detective work" (Hammond 2001: 24). The Croatian press enthusiastically reported that due to this breakthrough the loan of Livia's head would be extended for six more years. There

See also Neigebaur 1851: 119-120, 152-153; Paton 1862, I: 316; Patsch 1907: 94-95. 
were also speculations about a silent agreement that had been made between the two sides which would turn the loan into a permanent one (Anon. 2009: 14). "This is a really big gesture of the Ashmolean Museum where the head of Livia had until then been the ambassador of Croatian culture," Marin said (Kusin 2000: 3).

\section{A HEAD FOR A HAT}

As reported by Norman Hammond, the real story of the "Oxford" head of Livia began when Arthur Evans, in the 1870s, later to gain fame as the discoverer of the Minoan civilisation in Greece and the excavator of Knossos, was reporting on the political situation in the Balkans for the Manchester Guardian. Following in the footsteps of Sir Gardner Wilkinson, he visited the village of Vid in 1876 and 1878 (Evans 1876: 363, 1877: 365). During his visit there, he obtained some antiquities. Among them were two marble heads, "one of a Roman lady, the style of whose coiffure appears best to tally with that of the daughter of Diocletian and wife of Galerius, the Empress Galeria Valeria, though the workmanship would seem to belong to a better age; the other head is of Mercury, and is executed in a fine Græco-Roman style" (Evans 1885: 77). Livia's head remained in his possession until his death in 1941 when it was bequeathed to the Ashmolean Museum (Hammond 2004: 32, 2005: 55; Wilkes 2006: xiv).

Allegedly, Evans offered to pay for the marble heads, but the owner was supposedly only interested in Evans's English top hat, and would accept nothing else in exchange (Hammond 2000a: 24). ${ }^{2}$ So, Evans gave the hat to him "mainly to release the hat box as a suitable container for it (the head)" (Wilkes 2006: xiv).

In Marin's version of the event described in a monograph dedicated to the ancient Roman site of Narona the reader learns also who was the seller of the two heads:

Some 100 years ago, a young English archaeologist, Arthur Evans, came to Croatia. He visited Vid near Metkovic. The story goes that some villagers showed him two marble heads unearthed somewhere in the village and Evans said that he got these heads in exchange for his top-hat. After his death his widow gave the heads to the Ashmolean Museum in Oxford where they are still exhibited in the main hall. (Marin 1999: 307)

Marin's version of the story of how famous British archaeologist Evans had bartered his top hat for two marble heads, which were later identified as the heads of Livia and Mercury, and the seller being identified as a local 'peasant' or 'peasants' (seljak, seljaci) who had been carried away by Evans's top hat, became popular in the Croatian press (Kusin 2001: 25; Nadilo 2006: 43).

2 He was carrying, during his travel, a silk top hat made by Lock's of St James which his father, Sir John Evans, insisted on taking with "because he would be meeting many important people"; but he did never wear it (Hammond 2004: 32, 2005: 55; Wilkes 2006: xiv). 
I was told the same story during my visit to the village of Vid in the spring of 2003 by a curator in the Narona Archaeological Museum in formation, Ms. Ivana Bače. According to her, Sir Evans bartered his top hat with a peasant in exchange for the marble head of Livia (Bače 2003).

The Marin's addition in defining the seller as a peasant was small, but meaningful. In the last quarter of the nineteenth century, a top hat was a "generally recognised mark of 'better' circles" (Anon. 1909: 9). According to the British traveller to Dalmatia Maude Holbach, for instance, in the early twentieth century "the middle-class townsman" still clinged fondly "to his red Dalmatian cap," even though he combined it with an ordinary tweed suit. According to her, only the representatives of upper classes "adjured the national costumes for the fashions of Vienna" (Holbach 1908: 89-90; cf. Hutchinson 1909: 100).

If Holbach is a credible witness, it is highly unlikely that the seller of the marble heads who received the top hat was a seljak. The idea becomes even less acceptable if we take into account Antun Radićs observations published in Zbornik za narodni život i običaje Južnih Slavena, stating that those who wore "smart dress" at the close of the nineteenth century were not counted as prosti narod ("simple folk") but as more "civilised" people. According to Radić, the wearers of such clothings were those who "had lost a bit of their national soul" (Radić 1897: 3). Therefore, it seems very likely that the seller, or at least the middle-man, was a member of the Dalmatian "better circle," perhaps an archaeologist.

Coincidently, Mihovil Glavinić, the director of the Archaeological Museum in Split, saw the heads of Livia and Mercury long before Evans. He came across them during his archaeological excursion in September 1873 and described them in the Mittheilungen der k. k. Central-Commission zur Erförschung und Erhaltung der kunst-und historischen Denkmale (Glavinich 1878: xciv). Western travellers who paid attention to the archaeological treasures of Dalmatia recollected Director Glavinić as "an affable Cicerone" (Schweiger-Lerchenfeld 1883: 269) that is to say, a learned antiquarian who took the time to show and explain to Amand von Schweiger-Lerchenfeld (and other foreigners) the antiquities and curiosities of the country. Interestingly, he fully adopted Western style clothing already in the 1870 s. A French traveller Charles Yriarte, to whom Glavinić also served as a Cicerone during his visit to Solin in 1875, witnessed a short episode that he decided to preserve by drawing it:

While we were taking our rest in the vicinity of a but into the walls of which antique inscriptions were built in, a young girl from Salona, almost a child, dressed in her national costume, brought to Professor Glavinić an inscription she had found in a field. The archaeologist had thought these people, who every day dig these historical grounds, not to destroy any object, and, in compensation, when they bring him something, he gives them a small recompense in money. Stretching forward her hand upraised to receive the coins, the girl stayed confused for a while; but soon she took heart and asked if the inscription did not reveal that a treasure is buried 
at the place where she found it. We were laughing to such a naivety, but believed that it was right to leave the peasants in the conviction that each inscription could hide a treasure; it is the most secure way of prevention to destroy them. (Yriarte 1878: 172)

Yriarte, then, stressed that the local peasant girl was dressed in "national costume." Glavinić clothes are not described in this fragment; however, they are presented in the supplementary picture. On it, the reader sees a seated man wearing Western style clothes and a black top hat, studying the inscription found by the young girl. Yriarte's illustration gives readers an idea of the dress members of different classes in Dalmatia wore in the 1870 s and he also gives an insight into the position a native archaeologist held in the society of that period. Obviously, this position was quite ambiguous: he spoke the vernacular, but since the locals did not have a proper understanding of his work, he conversed easier with more cultured foreigners. $^{3}$

What would be the message of Marin's modification of the story, then? I personally see it as a warning to the local population of Dalmatia to beware of foreigners as potential buyers of antiquities, saying between the lines that whatever the price they pay for a certain artefact the seller will never be fully compensated. In other words, it is telling us that there still exists a certain gap between native archaeologists and members of the public who are seen by the former as lacking sufficient knowledge as to how important classical heritage is to Croatia.

\section{THE RISE AND FALL OF AN IMPERIAL SHRINE}

Unearthed, Narona sculptures were sent to the Archaeological Museum in Split, where they were fully renovated and put on display. Amongst them was also the torso of the "new" "Oxford-Opuzen Livia" statue which the town of Opuzen had lent to the Museum in 2002 (Kusin 2008a: 19). After some 1700 years, the Livia's head and body were reunited, forming the centre-piece of the exhibition which also recreated the other lost splendours of the ancient Augusteum. The exhibition titled Siesta of the Emperors of Narona in Split was conceived as the first step leading to the return of the sculptures to the in situ museum in the village of Vid.

The road from Split to the old Narona led them first to the Ashmolean Museum in Oxford where the statues were on display for three months in 2004 under the title The Rise and Fall of an Imperial Shrine: Roman Sculpture from the Augusteum at Narona. The exhibition aroused lively interest of the British public. A day before the opening of the exhibition The Times announced:

3 Judging from the memoirs written by Vladimir Rismondo where he recollects how he saw Don Fran Bulić for the first time as a young boy in Solin dressed in "a very traditional and black formal clerical clothes with-for him-strangely stiff hat put on his head" (Rismondo 1984: 203), native archaeologists kept on their outlandish costume-and their position-in the first half of the 20th century. 
Livia is back in Oxford, and with her head in the right place: a Roman statue of the murderous matriarch, put back together after many centuries as the result of an article in The Times, is spending the summer in the Ashmolean Museum, together with other sculptures from the imperial shrine where she was found. (Hammond 2004: 32)

As noted in Press Releases of the Ashmolean Museum, the centre-piece of the exhibition was the reunited torso of Livia from Opuzen and the marble head from the Ashmolean $\mathrm{Mu}-$ seum, acquired in 1878 by Sir Evans (Anon. 2004: 6). Emilio Marin delivered a special introductory lecture on 6 July 2004, in which he introduced the Augusteum of Narona and his discovery. In his lecture, Marin spiced the factography with the diplomatic phrases, giving the discovery a political connotation. According to the report in The Times, he said: "The Oxford-Opuzen Livia has turned into an ambassador of Croatian archaeology, and a goodwill ambassador between Croatia and Britain” (Hammond 2005: 55).

From Oxford, the exhibition travelled to Barcelona, Vatican and Zagreb. It was planned that at the time of the tenth anniversary of the discovery of the Augusteum all statues would return to the newly built in situ Narona Archaeological Museum in Vid to be put on a permanent exhibition. This did not happen, though. Neither the head of Livia nor its body have reached their final destination in Vid. So, instead of an anticipated happy end, there was a rather controversial twist in the story. When the touring statues returned to Zagreb, the statue of Livia fell apart, its original body being sent to Opuzen and replaced by a cast (Kusin 2008a: 19). The Opuzen authorities not only declined to donate "their" Livia, but also turned down proposals to give it to the Narona Archaeological Museum on loan. On the other hand, the Ashmolean Museum decided to further extend the loan solely under the condition that the head was placed on the original body, not on a cast.

\section{BEHEADED FOR THE SECOND TIME}

The archaeological findings in Vid in the mid 1990s inspired the idea of presenting this unique archaeological site in an integral fashion, including both architectural remains and other specimens of the ample archaeological materials. The corner-stone of the future museum was laid on 19 July 2004 and it was formally inaugurated on 18 May 2007. The main exhibition hall consists of the temple area itself, including the architectural remains of the Roman temple in situ and featuring the statues of emperors and their family members, mounted on a gallery overlooking a black-and-white mosaic floor. The permanent exhibition includes a total of roughly 900 finds, allowing visitors to track the settlement's history from the end of the $3^{\text {rd }}$ century BC through the $15^{\text {th }}$ century AD. The opening of the museum was considered of such an importance that the then Prime Minister of Croatia, Ivo Sanader, personally attended the opening ceremony. A group of local young boys dressed in "Roman" uniforms formed a double line to greet the prime minister. 
For Prime Minister Sanader, the new museum in Vid was a way-mark on the road to "Europe" and Croatian nationalism the appropriate vehicle for travelling along that road: We are heirs of the famous past which we must preserve, protect and bequeath it to the future generations. As we organise Croatia today, such our descendants will inherit, emphasised Sanader. When we recall Vid and Narona, we recall our glorious past, and the Valley of Neretva is a linkage of the antique and the Croatian past of an ancient Croatian place, the famous Neretva Valley of which we should be proud of, stressed Sanader. Important Museum in Vid was built by the whole Croatian nation, and the Government, i.e. the Ministry of Culture and the town of Metkovic procured the money and with its building we also defined ourselves as a nation, he states, saying that we will hand down this valuable heritage to our descendants on preservation, since this is not just a Croatian but also a European and universal heritage. The opening of the Museum is a great success for Vid, Metkovic, the Dubrovnik-Neretva Županija and Croatia, and with it Croatia has definitively drawn one more splendid project on the antique map of Europe. (Anon. 2007)

By building the Narona Archaeological Museum in Vid, the ruling Croatian elite endeavoured to show the world the "European" face of Croatia. They based their claims on the grounds of the ownership of the material remnants of classical antiquity: We possess important fragments of European heritage, therefore we are Europeans. However, instead of being evidence for the "Europeanness" of Croatia, the ownership of the remains of ancient Narona turned into a bone of contention between Metković and Opuzen. As a rule people treasure most what makes them important in the eyes of the others. In case of Opuzen this was the time when the town was an important administrative centre of the region. Therefore, it came as little surprise that the Opuzen Magistrate declined to comply with the expectations and recommendations of Croatian authorities and refused to donate "their" marble to the Narona Archaeological Museum. Under enormous media attention, they decided to build a "museum for one sculpture" on the main piazza of the town named after the Croatian King Tomislav. As the Mayor of Opuzen Ivo Mihaljević explained:

We are especially proud of Livia, because by erecting her statue on our piazza we will be able to realise a hundred years old dream of the inhabitants of Opuzen, including myself, who used to hear a lot about that when I was a child. (Soldo 2008a; Anon. 2008)

The architect Nenad Fabijanić, who designed plans for a regulation of the King Tomislav Square in Opuzen, agreed. For him, the statue of Livia was Opuzen's property; in his vision it should have been publicly presented and preserved in a special museum:

The museum will stand beside the St. Stephen church and in it the Empress Livia will testify on classical antiquity in the valley of the Neretva. There are many such examples in the world. Putting original antique elements 
in open-air or covered lapidaries is a European trend and Opuzen is no exception to this, said Fabijanic, stressing that this museum, when built, will be an architectonic master-piece. (Soldo 2008a)

In contrast, the Town Council of Metković, the nowadays administrative centre for the village Vid, invested a lot of money in the new museum. They expected all the statues originating from the Augusteum would find place under one roof, claiming the support of "domestic and universal cultural public who unanimously shared opinion about Livia being exhibited in Narona Archaeological Museum on the very same spot where it had been standing two thousand years ago." Seeing that it would not be possible to implement their plan, due to the decision taken by the Town Council of Opuzen, they protested vigorously and requested intervention from the Croatian state authorities. They insisted that a cast should do for the Square of King Tomislav in Opuzen. Deputy Mayor of Metković Mato Mustapić called the activities of the Opuzen authorities, who were "dreaming their hundred-year old dream" about their piazza with Livia on it "ridiculous and scornful." He compared the building of a "museum for one sculpture" in Opuzen with the conduct of the peasants of Vid who at the beginning of the twentieth century had built antique stones into their houses and stables, which later, damaged by the tooth of time, fell into ruins (Soldo 2008b).

\section{RAPING THE HISTORY}

The philosophical stipulation of having in possession an important piece of Roman art, served as the vindication of the present-day importance of the town Opuzen. Without "their" piece of classical heritage, they would be denied their claim to respect, if not their "Europeanness". Exalted apprehension of the Marins' discovery in the village of Vid in Croatian media and political parlance thus helped to formulate the very subversions it sought to discourage. Even though the Livia's torso was proclaimed a "cultural good of national importance" the Ministry of Culture and Croatian expert bodies were unable to 'soften' the Opuzen municipal authorities' decision to keep 'their' Livia. In September 2009, Vickers took the marble head back to Oxford (Kusin 2009: 9), and Marin allegedly congratulated those who set free the Livia from its captivity in the Archaeological Museum in Split and will put it again on display in the renewed Ashmolean Museum in Oxford. "I wish Livia to be there the ambassador of Narona and Croatian archaeology," he said (Anon. 2009: 14).

Reporting on the Livia's marble head almost-seven-year-long stay in Split, the Croatian press used the narrative of the happy end of an exciting archaeological story, and the project of building the first museum in situ in Croatia too important to fail. The epilogue of the story was not an anticipated one, though. As it actually happened, "after the body found its head, the head lost its body" (Kusin 2008a: 19). Namely, Opuzen authorities declined to play according with the script, as doing so would mean they should give away what were 'their' pieces of classical cultural heritage. At that time the Croatian press changed the 
narrative, adopting the language of strong criticism. Vesna Kusin, in particular, pointed the finger of strictures at Opuzen blaming them that-prior to Marin's discovery Opuzen did not care much for the marble statue of Livia (and a few other monuments from Narona)-, leaving them for years to stand "abandoned in dust and cobwebbery" in the vestibule of the Town Hall (Anon. 2008; Kusin 2009a: 9; 2009b: 19). After the celebrated discovery, they "selflishly craved to take hold of a piece of Narona cake, believing that with it a piece of fame would come down on them," but instead of fame for themselves, they only brought "a shame on Croatia" (Kusin 2009a: 9).

Opuzen authorities decided to put the original torso of Livia on public display on the piazza named after Croatian King Tomislav. First, they planned to put the marble torso under a glass bell, afterwards the idea occurred of a "museum for one statue" (Kusin 2008b: 19). To carry out their project they needed financial support of the state, but the Croatian Ministry of Culture declined the application as the cost for the Narona Archaeological Museum had already amounted to more than 24 million kuna. As it happens, then, Opuzen took back 'their' Livia only to put it into a huge wooden box and stored it in the Municipal Library Opuzen (Kusin 2009b: 19).

The Croatian press unanimously approved that the Opuzen application ended in failure. A cast of the Livia's torso, they argued, should have been made for display on the Opuzen piazza as it was made in the case of Florence, and the original should have been put into the Narona Archaeological Museum, where it would be better protected (Kusin 2007: 20, 2009a: 9, 2009b: 19). In the tense air of discontent, "Croatianness" of the statue vanished before the reader's eyes. Now, the Livia's torso was proclaimed a Roman artefact, a foreign body in Croatian culture. According to Vesna Kusin the Opuzen decision was badly chosen. It was, as if the town of Opuzen "broke off Livia's head for the second time." What made it completely inappropriate, was their plan to put it on show on the King Tomislav Square, or, as Kusin put it, "to push it into 'embrace' of the Croatian King Tomislav." It was this what "within European museum circles" brought the shame upon Croatia, instead of praise (Kusin 2007: 20). King Tomislav deserves a monument on the square of the same name, claimed the press, but without a 'Roman symbol' on it:

Besides, to put the Livia's statue next to the church of St. Stephen, the first Christian martyr, is out of place, to say the least. Opuzen has a splendid piazza, but from some other era and placing there a statue, which until 2001 was unknown to be Livia, seems to us as a rape of history. (Anon. 2008) Blaming Opuzen and their 'selfishness' had been so passionate that no question arose as to what happened with the Livia's head after Curator Vickers took it back to Oxford. In the Croatian press the question of cultural imperialism which played a role in Evans's obtaining of the Livia's head has never been raised, and the loan of the marble head was saluted as a "universal precedence" (Kusin 2000: 3; 2001: 25). In contrast, Opuzen's decision to keep the Livia's torso as their property was presented as Croatia's "shame within European museum circles" (Kusin 2007: 20). 
I visited the Ashmolean Museum on 7 February 2011. Then, in the main gallery, where the Livia's head had formerly been put on view, there stood just its plaster cast with an inscription explaining that "The original marble head is on long term loan to the Archaeological Museum of Split in Croatia.'”This was obviously not the case, as the original marble head stood just round the corner in the nearby gallery. As a result, not just one head, there were two of them to be seen: the original marble head and its plaster cast. They were silently letting know to the curious that the question of appropriation of cultural heritage is multifaceted due to its many faces.

\section{REFERENCES}

Anonymous

1909 Zgodovina in učinek prvega cilindra. Slovenski Narod, December 11, 9.

2004 Together after 1700 Years. Ashmolean Museum, Press Releases, 27 September, 6.

2008 Stoljetni san ili ...? Vijesti. May 8 (www.metkovic.hr).

2009 Kako je Livijina glava k'o bez glave pobjegla u Englesku. Metkovski Vjesnik, October 2, 14.

Bače, Ivana

2003 Personal information. Vid, March 19.

Bahr, Hermann

1909 Dalmatinische Reise. Berlin: S. Fischer Verlag.

Bond, George C. and Angela Gilliam (eds.)

1994 Social Construction of the Past: Representation as Power. London and New York: Routledge.

Bulić, Frane

1924-25 Razvoj arheoloških istraživanja i nauka u Dalmaciji kroz zadnji milenij. (Posebni otisak iz Zbornika Matice Hrvatske. VII. Prilog Vjesniku za arheologiju i historiju dalmatinsku, št. 48-49, godina 1924-1925.) Izabrani spisi. Split: Književni krug.

Evans, Arthur John

1876 Through Bosnia and Herzegóvina on Foot during te Insurrection, August and September 1875; With an Historical Overview of Bosnia; And a Glimpse at the Croats, Slavonians, and the Ancient Republic of Ragusa. London: Longamns, Green, and Co.

1878 Illyrian Letters. A Revides Selection of Correspondence from the Illyrian Provinces of Bosnia, Herzegovina, Montenegro, Albania, Dalmatia, Croatia, and Slavonia, Addressed to the 'Manchester Guardian' During the Year 1877. London: Longmans, Green and Co.

1885 Antiquarian Researches in Illyricum; Archaeologia XLVIII: 1-105.

Glavinich, Mich.

1878 Aus einem Reiseberichte des k. k. Conservator Mich. Glavinich. Mittheilungen der k. k. CentralCommission zur Erförschung und Erhaltung der kunst- und historischen Denkmale, xii-xiv.

Hammond, Norman

2000a How a murderous matriarch lost her head. The Times, October 25, 24.

2000b Oxford thrilled by headless torso discovery. The Times, November 22, 24.

2001a Two heads of Livia are better than one. The Times, April 3, 55.

2001b Body of evidence resolves the mystery of Livia's head. The Times, June 20, 24.

2004 Murderous matriarch comes to Oyford. The Times, July 6, 32.

2005 Croatia's commemorative stamp. The Times, April 4, 55. 
Holbach, Maude M.

1908 Dalmatia: The Land where East Meets West. London: John Lane, The Bodley Head; New York: John Lane Company.

Hutchinson, Frances Kinsley

1909 Motoring in the Balkans: Along the Highways of Dalmatia, Montenegro, the Hezergovina and Bosnia. Chicago: A. C. McClurg \& Co.

J.Z.N.

2000 Livija se vraća u Hrvatsku. Vjesnik, December 15, 3.

Jeličić-Radonić, Jasna and Darko Pereža

2010 Topografija antičke Salone (II). Istraživači Salone u XIX. stoljeću. Tusculum 3, 167-203.

Kusin, Vesna

2000 Svjetski presedan Ashmolean muzeja. Vjesnik, December 15, 3.

2001 Jedna glava, a dva tijela! Nedjelnji Vjesnik, June 24, 25.

2004 Splitska siesta naronskih careva. Nedjelnji Vjesnik, May 9, 19.

2007 Lakomo poglavarstvo. Vjesnik, May 21, 20.

2008a Bestjelesna Livija. Vjesnik, April 14, 19.

2008b Sumnja u Liviju? Vjesnik, May 26, 19.

2009 Hrvatska sramota. Vjesnik, September 28, 9.

2009b Zatočena baština. Vjesnik, October 26, 19.

Marin, Emilio

2004 Oxford-Opuzen Livia. In: Marin, Emilio and Michael Vickers (eds.), The Rise and Fall of an Imperial Shrine. Split: Arheološki muzej, 76-82.

Marin, Emilio and Michael Vickers

2004 The Rise and Fall of an Imperial Shrine. Split: Arheološki muzej.

Marin, Emilio et al.

1999 Narona.Zagreb: Naro naklada; Opuzen: Neretvanska riznica umjetnina i inih vrijednosti.

Marin, Emilio (ed.)

2000 Arheološki muzej-Split AD 2000. Split: Arheološki muzej.

Nadilo, Branko

2006 Muzej Narona u Vidu pokraj Metkovića. Gradevinar 1: 41-50.

Neigebaur, Johann Daniel Ferdinand

1851 Die Süd-Slaven und deren Länder in Beziehung auf Geschichte, Cultur und Verfassung. Leipzig: Costenoble \& Remmelmann.

Paton, A. A.

1862 Researches on the Danube and the Adriatic; or, Contributions to the Modern History of Hungary and Transylvania, Dalmatia and Croatia, Servia and Bulgaria. London: Trübner and Co.

Patsch, Carl

1907 Zur Geschichte und Topographie von Naroda. Wien: In Kommission bei Alfred Hölder.

Preziosi, Donald

2006 In the Aftermath of Art: Ethics, Aesthetics, Politics. London and New York: Routledge.

Prusac, Marina

2009-2011 The Missing Portraits from the Augusteum at Narona. In: Zbornik KačićXLI-XLIII. Split, 509-534.

Radić, Antun

1897 Osnova za sabirańe i proučavańe građe o narodnom životu. Zbornik za narodni život i običaje Južnih Slavena II: $1-88$. 
Rismondo, Vladimir

1984 Uspomene na don Franu Bulića. In: Marin, Emilo (ed.), Don Frane Bulić. Split: Arheološki muzej, 203-205.

Schweiger-Lerchenfeld, Amand Freiherr von

1883 Die Adria. Land-und Seefahrten ime Bereiche des Adriatischen Meeres. Wien, Pest, Leipzig: A. Hartleben's Verlag.

Soldo, Stanislav

2008 Muzej iz Oxforda uzima glavu rimske carice. Jutarnji list, April 8, p. 10.

2008a Opuzenci za Liviju grade „mini muzej“. Slobodna Dalmacija, May 4.

2008b U Opuzen će kip carice Livije, u Naronu original. EPEHA, May 15.

Vickers, Michael

2001 Livia Narona. The Ashmolean 40: 9-10.

Wilkes, John J.

2006 Introduction. In: Evans, Arthur J., Ancient Illyria: An Archaeological Exploration. London and New York: I. B. Tauris, 1-xvii. (The inaugural lecture - Arthur Evans in the Balkans 1875/81 - was delivered, in a slightly shortened version, at the Institute of Archaeology on Tuesday, 28 October 1975, under the chairmanship of Professor J.D. Evans, F. B. A., Director of the Institute.)

Wilkinson, John Gardner

1848 Dalmatia and Montenegro: with a Journey to Mostar in Herzegovina. London: John Murray.

Yriarte, Carlo

1878 La Dalmazia. Milano: Fratelli Treves.

\section{CESARICA Z DVEMA GLAVAMA}

Konec 20. stoletja je direktor Arheološkega muzeja v Splitu Emilio Marin med izkopavanji v vasi Vid odkril imeniten preostanek rimske preteklosti, tempelj avgusteum. Domneval je, da je bil v templju tudi kip Avgustove žene, cesarice Livije, saj njen kult v Naroni potrjujejo napisi, izkopani v Vidu, in portretna glava, ki jo hranijo v Ashmolejevem muzeju v Oxfordu; pridobil jo je Arthur Evans leta 1878. Marinova domneva je bila objavljena v dnevniku The Times 25. oktobra 2000 skupaj z njegovim pozivom, naslovljenim na Ashmolejev muzej, naj vrne glavo na Hrvaško. Upravni organ muzeja je imel prav naslednjega dne sestanek, na katerem so se odborniki odločili poslati Livijino glavo na enoletno sposojo v Arheološki muzej Split. Ko je kustos Vickers prinesel Livijino glavo iz Oxforda $v$ Split, so neuspešno skušali združiti glavo s trupom kipa, ki naj bi domnevno pripadal Liviji. Zato je Marin nadaljeval z iskanjem torza, ki bi ustrezal glavi iz Oxforda. Iskanje je pritegnilo veliko pozornost tiska, najbolj hrvaškega, manj pa britanskega, ki je sicer odprto podpiral zamisel o vrnitvi marmorne glave na Hrvaško. Marin je v mestni hiši bližnjega mesta Opuzen naposled našel ustrezen trup v naravni velikosti in leta 2001 sta bila Livijina glava in trup bila spet združena. Hrvaški tisk je navdušeno poročal, da bo zaradi tega uspeha sposoja Livijine glave podaljšana za šest let. Pojavile so se tudi spekulacije o tihem sporazumu, ki naj bi ga sklenili obe strani, namrec, da bi sposoja ostala trajna. Arheološka odkritja $v$ Vidu sredi 90 . let so porodila zamisel o celoviti predstavitvi tega enkratnega arheološkega najdišča, vključno z arhitekturnimi ostanki in drugimi primerki bogatega arheolo- 
škega materiala. Temeljni kamen bodočega muzeja je bil vzidan 19. julija 2004, muzej pa je bil formalno odprt 18. maja 2007. Glavna razstavna dvorana je tempelj sam, v njej so razstavljeni arhitekturni ostanki rimskega templja in situ in kipi cesarjev in članov njihovih družin, postavljeni v galerijo nad črno-belim talnim mozaikom. Stalna razstava obsega v celoti kakšnih 900 najdb in omogoča obiskovalcem, da spremljajo zgodovino naselbine od konca 3. stoletja pr. $n$. št. do 15. stoletja. Odprtje muzeja je bilo tako pomemben dogodek, da ga je z obiskom počastil tedanji predsednik hrvaške vlade Ivo Sanader. Skupina lokalnih mladcev, oblečenih v "rimske" uniforme, se je za to priložnost postavila $v$ špalir, s katerim so pozdravili premierja.

Ko je poročal o skoraj sedemletni sposoji Livijine marmorne glave v Splitu, je hrvaški tisk pisal o srečnem koncu napete arheološke zgodbe in projektu zgraditve prvega hrvaškega muzeja in situ kot preveč pomembnem, da se ne bi posrečil. Epilog zgodbe pa se ni skladal s pričakovanji, saj se je mestna oblast Opuzena odlocila izvirni torzo Livije razstaviti na trgu, poimenovanem po hrvaškem kralju Tomislavu. Za uresničitev projekta so potrebovali finančno pomoč države, vendar je hrvaško ministrstvo za kulturo zavrnilo prošnjo, ker so stroški zgraditve Arheološkega muzeja Narona že presegli 24 milijonov kun. Dejansko je Opuzen tako vzel "svojo" Livijo, jo shranil v ogromen lesen zaboj in uskladiščl v Mestni knjižnici Opuzen.

Oštevanje Opuzena in njegove "sebičnosti "je bilo tako vročekrvno, da ni nihče vprašal, kaj se je zgodilo z Livijino glavo potem, ko jo je Vickers odnesel nazaj v Oxford. V hrvaškem tisku ni bilo postavljeno vprašanje kulturnega imperializma, ki je bil gibalo, da je Evans pridobil Livijino glavo. Sposojo marmorne glave so pozdravljali kot "univerzalni precedens", medtem ko so odločitev Opuzena, da obdrži njen torzo kot svojo lastnino, predstavili kot hrvaško "sramoto $v$ evropskih muzejskih krogih".

Ashmolejev muzej sem obiskal 7. februarja 2011. Tedaj je bil v glavni galeriji, kjer je bila Livijina glava prvotno postavljena na ogled, razstavljen zgolj njen mavčni odlitek s pojasnilom: "Izvirna marmorna glava je na dolgoročni sposoji v Arheološkem muzeju v Splitu, Hrvaška. "To ocitno ni bilo res, saj je bila izvirna marmorna glava razstavljena v sosednji galeriji. Razstavljena torej ni bila ena sama glava, temveč dve: izvirna marmorna glava in njena mavčna kopija. Obe skupaj sta radovednemu molče sporočali, da je vprašanje prisvajanja kulturne dediščine večplastno vprašanje z več obrazi.

Prof. Dr. Božidar Jezernik, Department of Ethnology and Cultural Anthropology, Faculty of Arts, Aškerčeva 2, SI-1000 Ljubljana, Slovenia, Bozidar.Jezernik@ff.uni-lj.si 